\title{
Analysis of school factors associated with the physical fitness of high school students
}

\section{Analýza vplyvu prostredia školy na úroveň telesnej zdatnosti študentov stredných škôl}

\author{
Jan Junger, Lenka Tlučáková, Andrea Palanská \\ Faculty of Sports, University of Prešov, Slovakia
}

\begin{abstract}
The purpose of this study was to determine the association between physical education environment and physical fitness levels of students at selected Slovak high schools.

Methods: For the purposes of the study, 12 high schools in the Prešov region were selected via cluster sampling. To determine the association between physical education environment and physical fitness levels, 705 students (287 girls, 418 boys) participated in the study. The quality of physical education classes was assessed using selected items of a questionnaire used in a Texas youth fitness project, each school's physical education environment and policy survey. Data on muscular strength, endurance, flexibility and BMI were collected using the FITNESSGRAM test protocol. To determine the effect of school physical education environment on fitness levels, ordinary least squares regression was used. Analysis of the association between school physical education environment and fitness levels showed minimal differences. The results indicated positive effects of qualified teachers and class size on fitness level measured by selected items of the FITNESSGRAM test battery in high school students. The educational attainment and participation in conferences by teachers and the number of students per class appeared to be the most significant predictors affecting the physical fitness of high school students.
\end{abstract}

\begin{abstract}
Abstrakt
Cielom štúdie bolo popísat'vzt'ah medzi prostredím školy a telesnou zdatnostou študentov vybraných stredných škôl. Do štúdie boli zapojení študenti a študentky dvanástich náhodne vybraných stredných škôl Prešovského samospravného kraja.

Do výskumu bolo zapojených 705 študentov (287 dievčat, 418 chlapcov). Kvalita materiálneho vybavenia a prostredia školy bola hodnotená na základe použitia dotazníka vypracovaného $v$ rámci Texas youth fitness project. Na základe použitia FITNESSGRAMU sme získali údaje o svalovej sile, vytrvalosti, flexibilite a BMI.

Vztah medzi faktormi prostredia a telesnou zdatnostou študentov sme zistovali pomocou regresie, ktorá ukázala malé rozdiely medzi jednotlivými školami. Výsledky naznačujú pozitívny vplyv stupña vzdelania učitel'a, jeho účasti na konferenciách a vel'kosti tried študentov na vybrané parametre telesnej zdatnosti študentov.
\end{abstract}

\section{Key words}

school physical educational program, Fitnessgram, youth fitness, school environment

\section{Klíčová slova}

školní program tělesné výchovy, Fitnessgram, zdatnost mládeže, školské prostředí

The paper was supported by Slovak Research and Development Agency on the basis of agreement no. $A P V V-0768-11$. 
Physical activity in childhood is known to have both short and long term health benefits (Andersen et al.,2006; Biddle, Gorely, \& Stensel, 2004), whilst physical inactivity in children has been linked to rises in childhood obesity (Wareham, Van Sluijs, \& Ekelund, 2005). Rapid increase in childhood obesity and decreases in other physical fitness components have become a major concern worldwide (Zhu, Welk, Meredith, \& Boiarskaia, 2010b). Over the last 20 years, we can observe a decrease of $0.4 \%$ in $20-\mathrm{m}$ shuttle endurance run performance among children (Tomkinson, Léger, Olds, \& Cazorla G, 2003).

There are plenty of known factors associated with childhood obesity as well as with a decrease in physical fitness. They include genetic, behavioral and environmental factors (Dietz \& Gortmarker, 1985; Farooqi \& O’ Rahilly, 2000; Morland, Wing, Diez, \& Poole, 2002). The drivers of physical activity are many and varied but there is increasing recognition of the importance of the physical environment (Sallis et al., 2001; Sallis, Prochaska, \& Taylor, 2000). In the case of children, the environment of the school may have a particularly significant influence on physical activity, a deficiency of which is also associated with childhood obesity. Expanding physical education programs in schools may be an effective intervention for combating obesity (Datar \& Sturm, 2004). Also correlations between physical activity and movement skills are well known (Hume et al., 2008). Different components of the school environment have been shown to influence physical activity in children and a recent systematic review has highlighted the potential of interventions which target school environments (Van Sluijs, Mcminn, \& Griffin, 2007). Considering that children spend much of their day during the week at school (Verstraete, Cardon, De Clercq, \& De Bourdeaudhuij, 2006; Wechsler, Devereaux, Davis, \& Collins, 2000), it is necessary to focus on factors of the school environment as a possible determinant influencing the quality of physical education.

According to Starc and Strel (2012), the quality of physical education depends on five factors: allocated time, available facilities and equipment, the contents of the physical education curriculum, the number of children per teacher and an individual teacher's competencies. Datar and Sturm (2004) also present in addition to the above mentioned factors the following: appropriate assessment procedures, positive administrative support and appropriate policies. Other studies also confirmed that school environments with high levels of supervision and improvements stimulated girls and boys to be more physically active (Harrisonn \& Jones, 2012; Sallis et al., 2000). According to Zhu, Boiarskaia, Welk, and Meredith (2010a), the level of fitness achieved by students is also influenced by a number of school physical education programs and policy factors (teachers' training, recess time, available space for physical activity, establishment of a school wellness policy and practicing fitness testing before administration).

A number of other factors may have an influence on the amount of youth physical activity (Zhu, et al., 2010b). The two most direct indicators for physical activity are physical education time, i.e. the number of physical education classes per week and the length of the class and recess time (Dale, Corbin, \& Dale, 2000). These factors are often associated with school physical education policies. For example, in Slovakia, the number of physical education classes as well as the length of class at schools is regulated by the Ministry of Education, Science, Research and Sport through state educational programs. Similarly, if the policy requires that physical education class be taught by a physical education specialist, the quality of physical education should be better than in a school without such a policy concerning teachers training requirements (Zhu et al., 2010b).

No less important is the effect of the quality and quantity of sport equipment and school facilities (playground, field and track, indoor and outdoor facilities, etc.) on the level of physical education classes (McKenzie et al., 2001).

\section{Methods}

For the purposes of the study, 12 high schools in the Prešov region were selected via cluster sampling. To determine the association between physical education environment and physical fitness levels, 705 students ( 287 girls, 418 boys) participated in the study. The quality of the physical education 
classes was assessed using selected items of a questionnaire used in a Texas youth fitness project, each school's physical education environment and policy survey.

In the study, we analyzed physical fitness and data on muscular strength, endurance and flexibility were collected using the FITNESSGRAM test protocol. In these tests we focused on achieving the HFZ (Healthy Fitness Zone) expressed as a percentage.

Participant's legal representative (in the case when a child was younger than 18 years) or participants (in the case when a child was older than 18 years) received a verbal description of the study procedures before testing and completed a written informed consent that was approved by the ethical committee of Presov University in Presov. Measurements were taken according to the ethical standards of the Declaration of Helsinki (Harriss \& Atkinson, 2011).

\section{Data Analysis}

To compare the school environments, we used Cluster Analysis (CLU); to be more specific, we used the group average method, which is appropriate especially when objects have a natural tendency to group. The detected clusters represent the data structure only with respect to the selected characteristics.

The efficiency of the clustering method was identified on the basis of the maximal value of the cophenetic correlation coefficient (CC) - between the real distance and the distance predicted by dendrogram.

The values are listed in Table 1. Values higher than $\mathrm{CC}=75$ indicate that it is possible to consider the clustering efficient. The lowest values close to zero in Delta (0.5) and Delta (1.0) criteria serve for the assessment of the goodness-of-fit for cluster analysis.

Ordinary least squares regression (OLS) uses the method of least squares to estimate the "best fit" of a set of independent $(\mathrm{X})$ variables against the dependent variable $(\mathrm{Y})$ you wish to explain or predict.

OLS was used to examine the impact of physical education programs, teacher demographics, teacher training, length of physical education, facilities and physical education policy on children's physical fitness levels.

\section{Results}

To compare the homogeneity of school environments, we used cluster analysis. Results of the cluster analysis are depicted in a horizontal dendograph (Figure 1). On the basis of the similarity of statistical units we may see three major clusters:

1. Stará L’ubovňa, Vranov nad Topl'ou - schools from Svit, Humenné and Medzilaborce were gradually added here;

2. The second cluster consists of Stropkov and High school specializing in health care in Prešov; Kežmarok was added, too;

3. The third group includes the Hotel Academy (Catering College) in Prešov and the secondary grammar school in Sabinov.

In-depth analysis indicated the following similarities of the statistical units. Cluster 1 consists of schools where physical education classes are taught by teachers with a master's degree (M.A.); teachers who have taught physical education for more than 20 years and in the past completed sufficient education or training related to physical education; however, they do not participate in professional conferences. The schools from this cluster have neither their own playground to perform physical activities and games nor a soccer field.

The second cluster consists of the schools where teachers have taught physical education for no longer than 4 years; they do not participate in supplementary courses or professional conferences related to school physical education. Physical education classes at these schools merge and last for 60 minutes at least, including time for changing clothes and hygiene. The schools do not have their 
own soccer field, indoor or outdoor areas for physical education lessons and extracurricular physical activities.

The third cluster includes schools where teachers with various lengths of experience and different levels of education (master's degree, post-grad ( $\mathrm{PhD}$ ) student) are employed. These teachers attended courses dealing with physical education in the past and also participate in conferences. The classes last for 45 minutes at most. These schools have playgrounds for physical activities and games, soccer field and indoor and outdoor areas are available for school physical education and extracurricular physical activities as well.

The HFZ percentage is demonstrated in Table 1. A similar HFZ percentage in students would predict a certain effect of the common characteristics of the environment on their physical fitness. However, Table 2 indicates high heterogeneity of HFZ percentage in the second cluster as well as in the first cluster. In the third cluster, we may observe similarities in the HFZ percentage in tests of flexibility of lower and upper extremities.

Based on the in-depth analysis of environmental conditions, conditions of the schools from the third cluster may be considered as of the highest quality. On the basis of this finding, it is possible to expect a positive effect on the level of physical fitness. This assumption has been confirmed to a certain extent; based on the data presented in Table 2 we can state that the HFZ percentage was highest in strength tests. Since not all schools are attended by girls, to assure an objective assessment, we only used data collected from boys. In the test of abdominal muscle strength, the schools from the first cluster achieved HFZ $69.73 \% ; 55.17 \%$, from the second cluster $23.52 ; 100.00 \%$ and from the third cluster $68.00 \%$ and $75.00 \%$.

In the test of upper limb strength, the results HFZ were again in favor of the third cluster, i.e. $92.00 \%$ and $93.75 \%$.

In further statistical investigation and regression analysis, factors of environment quality, which are characteristic for the third cluster, appear to be positive predictors of HFZ percentage in students (Tables 4, 5, 6, 7, 8).

Table 3 demonstrates descriptive statistics of achieving the HFZ in all students together and according to their gender. We only found small differences in meeting the recommendations between girls and boys in the tests of abdominal strength and endurance $(67.95 \% ; 67.16 \%)$ and shoulder stretch test $(89.39 \%$; $94.81 \%)$. The most significant differences were observed in $90^{\circ}$ Push Up test in favor of boys $(89.63 \% ; 50.37 \%)$.

Tables 4-8 report specific results for each variables for Curl Up, $90^{\circ}$ Push Up, Back-Saver Sit \&Reach, Shoulder Stretch tests, respectively.

The curl-up test indicates abdominal muscle (trunk) strength, which is primarily influenced by the volume of the executed physical activity, which assumes the association of achieving the HFZ in this test with length of physical education classes and their amount. In our case, statistically significant factors included facts concerning teacher's personality, his/her education, length of work experience, etc. (Table 4).

Similarly to the curl-up test, the push-up test also indicates strength but in this case it is lower limb strength. A logical assumption of the environment's influence was supported by most of our findings which indicate the effect of the quality and efficiency of the lesson on this parameter (teacher's experience, participation in conferences, number of days when P.E. is taught, teaching load, number of students per class, possessing playground, access to and use of grant funds). More detailed results are presented in Table 5.

Due to a number of factors that influence the level of flexibility (genetics, body composition), we did not expect statistically significant associations between the school environment and the level of flexibility in the upper and lower limbs. Statistically significant predictors are listed in Table 6 . In terms of meeting the HFZ criteria in flexibility tests, they included teacher's gender, participation in conferences, possession of a playground for implementation of physical activities, existence of a board for nutrition and physical activity and assessment of the physical education. 
When investigating a relationship between the dependent variable and several independent variables we found out that there is association between student's flexibility and information on the frequency of physical education classes, the daily teaching load and the number of students per class. Results of this analysis are presented in Table 7. In questions dealing with education and experience, we detected a statistically significant difference in the question concerning the teacher's participation in professional conferences.

$\mathrm{P}$-value of the constant was also significant in questions focused on the environment and conditions of individual schools, specifically in schools that had a playground for physical activities and games, soccer field and indoor and outdoor areas for teaching physical education and extracurricular activities.

Analysis of all data is presented in Table 8. Out of all selected FITNESSGRAM-related variables only two environmental factors were statistically significant, namely participation in conferences and the number of students per class.

\section{Discussion}

Generally, we may consider conditions in Slovak high schools more uniform in relation to P.E. teachers' education than in similar schools abroad. Huge heterogeneity, however, can be found in the material equipment of the schools.

The level of physical development and physical fitness is certainly affected by the number of P.E. classes in schools. In Slovakia, there are two obligatory classes (90 min) of physical education in each elementary and high school and with this number we are in last place within European countries. One class mostly lasts for 45 minutes including time for changing clothes and hygiene.

The national curriculum allows schools to extend physical education by one or more classes a week but in practice it does not happen. These, so called "optional" classes are rather given to other subjects. Three classes of physical education in the curriculum are unreal for elementary schools. They are not capable of ensuring material conditions and facilities, gyms, playgrounds, sport equipment or staff. The current desire for three classes of physical education per week is also supported by European Union legislation which suggests increasing the number of P.E. classes to 3 per week (Štátny pedagogický ústav, 2008). However, an elevated number or P.E. classes would not automatically mean an increase in physical fitness since a qualitative factor of P.E. implementation plays a very important role. Moreover, neither result of our research significantly identified any direct relationship between the number of P.E. classes per week and the level of students' physical fitness (Table 4-8). An increase in the number of P.E. classes would have a significant effect mainly in students who are only physically active in P.E. classes.

Also we can observe a kind of homogeneity in Slovak schools in the level of teachers' minimal educational attainment where the minimal level of a P.E. teacher's education attained has to be a Master's degree; however, some teachers even increase their qualification to doctoral level. On the basis of our results, we may consider this aspect a factor significantly affecting the level of students' physical fitness in Slovak high schools (Table 4-8).

A full-time teacher's teaching load is 37.5 hours per week. It includes 23 contact classes and preparation time of up to 20 minutes per class. The teaching load includes further administrative work, supervision during teaching as well as breaks, preparing students for competitions and involvement in extra-curricular activities and clubs.

The greatest heterogeneity can be observed in material equipment of the schools and it mainly depends on the number of students attending the schools, i.e. the size of the school (Junger, 1989; Kandráč \& Nemec, 2013). During the research we came across schools that do not have their own gym for physical education. Usually, they solve this situation by renting the facilities (gym, sport hall) from the town or a neighboring school which possesses such facilities. Thus many times must students commute on foot for a P.E. class; a journey can last for several minutes. Physical Education classes are often merged so that in one gym, or hall, several groups are taught simultaneously and many teachers perceive this situation as a problem with lower efficiency of the teaching process. 
The number of students in a given P.E. class is crucial in terms of efficiency. In our study, this logical assumption was also confirmed at a statistical level and summary results are listed in Table 8 .

Less than half of the schools included in the study have their own playground (41.66\%), soccer field $(50.00 \%)$ or track and field (41.66 \%) for the purpose of physical education classes. On the contrary, three quarters of the teachers assessed the gyms as well equipped.

Better material conditions are often considered a factor affecting the quality of the physical education process, which assumes an elevated level of students' physical fitness (McKenzie et al., 2001). However, our results do not clearly confirm this fact. Material conditions are only in some cases predictors influencing achieving the HFZ of students' physical fitness (Table 8).

Improving material conditions for physical education classes is also possible through implementation of grant projects and projects focused on physical education. In Slovak schools, the use of projects is not a common practice yet; out of all tested schools, just over $40 \%$ used these projects. Implementation of projects and financial management is an matter of internal policy of each school and to a large extent it depends on the principle what the school budget will be used for and whether it is in his/her interest to invest in development and improvement of P.E. classes.

Physical Education classes in our conditions are not cancelled due to extreme weather.

Classification, fairness and objectivity of assessment in P.E. are among the most discussed topics, especially due to its specific content and implementation. In Slovakia, Physical Education, together with Music and Art, belong to educational courses. Classification of physical education is not compulsory in all schools and each school decides about it at the beginning of each school year. Concerning classification, it is governed by the methodological guideline of the Ministry of Education, Science, Research and Sport of the Slovak republic. The most important in the assessment is the student's approach, attitude and relationship to physical activity and physical education, the student's physiological development and development of physical abilities and physical fitness, taking into account the student's individual predispositions and improvement and fixing of motor skills. The classification degree is set by the teacher who teaches Physical Education.

The student, who on the basis of a medical report could not complete the physical activity content of the classes during the classification period, will be assessed on his/her school report as "exempt".

Graded P.E classes are common practice in our schools; all of our tested schools did so but almost $20 \%$ of the teachers said that grades given in the P.E. classes do not reach the level of other subjects and are often greatly exaggerated. Teachers have often tendencies to augment or enhance the assessment; one of the reasons is the core mission of this subject which should not be the aim but rather a means for motivation to perform physical activity in life.

\section{Conclusion}

In the study, we attempted to reveal the effect of the environment of physical education implementation on the level of students' physical fitness. It is very difficult to identify predictors which would, despite a low number of contact classes, directly influence the examined parameters in the tests.

There are plenty of factors which could influence the results of achieving the HFZ in students, such as genetics, children's interests, ways of spending free-time, etc., which were not included in our questionnaire. Moreover, the results of correlation analysis indicate effects of other hidden variables. Further studies should deal with a more detailed analysis of other, herein unmentioned variables.

Research of this issue contributed to distribution of information on the effect of the school environment and its individual factors on youth physical fitness. Teacher's education and his/her subsequent participation in professional conferences and the number of students per class appeared to be the most significant predictors influencing students' physical fitness. Therefore we believe that it is important to implement the obtained theoretical information in school practice.

The institutional review board approved the research. All participants confirmed their participation in this research. 


\section{References}

Andersen, L. B., Harro, M., Sardinha, L. B., Froberg, K., Ekelund, U., Brage, S. et al. (2006). Physical activity and clustered cardiovascular risk in children: a cross- sectional study. International Journal of Pediatric Obesity, 3(Suppl. 1), 58-66.

Béderová, A. (2003). Príloha o racionálnej výžive v škole a rodine. Prevencia a učitelia. Rodina a škola, 1, 29.

Biddle, S. J. H., Gorely, T., \& Stensel, D. J. (2004). Health-enhancing physical activity and sedentary behaviour in children and adolescents. Journal of Sports Science, 22, 679-701.

Centers for Disease Control and Prevention. (2006). Prevalence of Overweight Among Children and Adolescents: United States, 2003-2004.

Dale, D., Corbin, C. B., \& Dale, K. S. (2000). Restricting opportunities to be active during school time: Do children compensate by increasing physical activity levels after school? Research Quarterly for Exercise and Sport, 71, 240-248.

Datar, A., \& Sturm, R. (2004). Physical Education in Elementary School and Body Mass Index: Evidence from the Early Childhood Longitudinal Study. American Journal of Public Health, 94, 1501-1506.

Dietz, W. H., \& Gortmarker, S. L. (1985). Do we fatten our children at the television set? Obesity and television viewing in children and adolescents. Pediatrics, 75, 807-812.

Farooqi, I. S., \& O' Rahilly, S. (2000). Recent advances in the genetics of severe obesity. Archives of Disease in Childhood, $83,31-34$.

Harrison, F., \& Jones, A. P. (2012). A framework for understanding school based physical environmental influences on childhood obesity. Health \& Place, 18, 639-648.

Harriss, D. J., \& Atkinson, G. (2011). Update - Ethical Standards in Sport and Exercise Science Research. International Journal of Sports Medicine, 32(11), 819-821.

Hume, C., et al. (2008). Does Weight Status Influence Associations between Children's Fundamental Movement Skills and Physical Activity? Research Quarterly for Exercise and Sport, 79, 158-165.

Junger, J. (1989). Analýza stavu materiálno-technického zabezpečenia telovýchovného procesu na stredných školách Východoslovenského kraja. Zborník hlavných referátov s koreferátov z vedeckej konferencie: Progresívne trendy výučby v telovýchovnom procese, 1, 287-282.

Kandráč, R., \& Nemec, M. (2013). Materiálne podmienky pre výučbu atletiky na základných školách. Acta Facultatis exercitationis corporis universitatis Presoviensis, 1, 76-80.

McKenzie, T. L., Stone, E. J., Feldman, H. A., Epping, J. N., Yang, M., Strikmiller, P. K., et al. (2001). Effect of the CATCH physical education intervention: Teacher type and lesson location. American Journal of Public Health, 21, 101-109.

Morland, K., Wing, S., Diez Roux, A., \& Poole, C. (2002). Neighborhood characteristics associated with the location of food stores and food service places. American Journal of Preventive Medicine, 22, 23-29.

Sallis, J. F., Conway, T. L., Prochaska, J. J., Mckenzie, T. L., Marshall, S. J., \& Brown, M. (2001). The association of school environments with youth physical activity. American Journal of Public Health, 91, 618-620.

Sallis, J. F., Conway, T. L., Prochaska, J. J., McKenzie, T. L., Marshall, S. J., \& Brown, M. (2001). The Association of School Environments with Youth Physical Activity. American Journal of Public Health, 91, 618-620.

Sallis, J. F., Prochaska, J. J., \& Taylor, W. C. (2000). A review of correlates of physical activity of children and adolescents. Medicine and Science in Sports and Exercise, 32, 963-975.

Starc, G., \& Strel, J. (2012). Influence of the quality implementation of a physical education curriculum on the physical development and physical fitness of children. BMC Public Health, 12(61), 2-7.

Štátny pedagogický ústav. Štátny vzdelávací program ISCED 3. (2008). Retrieved from: http://www.statpedu.sk/files/ documents/svp/gymnazia/isced3_spu_uprava.pdf

Tomkinson, G. R., Léger, L. A., Olds, T. S., \& Cazorla G. (2003). Secular trends in the performance of children and adolescents (1980-2000): An analysis of 55 studies of the 20-m shuttle run test in 11 countries. Sport Medicine, 33, 285-300.

Van Sluijs, E. M. F., McMinn, A. M., \& Griffin, S. J. (2007). Effectiveness of interventions to promote physical activity in children and adolescents: Systematic review of controlled trials. British Medical Journal, 335, 703-707.

Verstraete, S. J. M., Cardon, G. M., De Clercq, D. L. R., \& De Bourdeaudhuij, I. M. M. (2006). Increasing children's physical activity levels during recess periods in elementary schools: The effects of providing game equipment. European Journal of Public Health, 16, 415-419.

Wareham, N. J., Van Sluijs, E. M. F., \& Ekelund, U. (2005). Physical activity and obesity prevention: A review of the current evidence. Proceedings of the Nutrition Society, 64, 229-247.

Wechsler, H., Devereaux, R. S., Davis, M., \& Collins, J. (2000). Using the school environment to promote physical activity and healthy eating. Preventive Medicine, 31, 121-137.

Zhu, W., Boiarskaia, A., Welk, G. J., \& Meredith, M. D. (2010a). Physical education and school contextual factors relating to student's achievement and cross-grade differences in aerobic fitness and obesity. Research Quarterly for Exercise and Sport, 81, 53-64.

Zhu, W., Welk, G. J., Meredith, M. D., \& Boiarskaia, E. (2010b). A survey of physical education programs and policies in Texas schools. Research Quarterly for Exercise and Sport, 81, 42-52. 
Table 1. Clustering table on the basis of the maximal value of the correlation coefficient

\begin{tabular}{|c|c|c|c|}
\hline Method & CC & Delta (0.5) & Delta (1.0) \\
\hline Single Linkage & 0.592154 & 0.223260 & 0.279455 \\
\hline Complete Linkage & 0.613062 & 0.186484 & 0.240799 \\
\hline Simple Average & 0.773209 & 0.085764 & 0.109950 \\
\hline Group Average & 0.780549 & 0.083289 & 0.106661 \\
\hline Centroid & 0.655095 & 0.645284 & 0.746596 \\
\hline Median & 0.694530 & 0.458086 & 0.531790 \\
\hline $\begin{array}{c}\text { Warad's Minimum } \\
\text { Variance }\end{array}$ & 0.620217 & 0.457260 & 0.536819 \\
\hline Flexibile Strategy & 0.250692 & 0.771866 & 0.812927 \\
\hline
\end{tabular}

Note. $\mathrm{CC}=$ correlation coefficient

Table 2. Descriptive statistics of Healthy Fitness Zone percentages in schools from individual clusters

\begin{tabular}{|c|c|c|c|c|c|}
\hline School & & Curl-Up & $90^{\circ}$ Push Up & Back-Saver Sit \& Reach & Shoulder Stretch \\
\hline \multirow[t]{3}{*}{1} & Overall & 69.73 & 86.84 & 15.78 & 82.89 \\
\hline & Boys & 69.73 & 86.84 & 15.78 & 82.89 \\
\hline & girls & - & - & - & - \\
\hline \multirow[t]{3}{*}{8} & Overall & 60.31 & 65.07 & 42.85 & 100.00 \\
\hline & Boys & 55.17 & 89.65 & 55.17 & 100.00 \\
\hline & girls & 64.70 & 44.11 & 32.35 & 100 \\
\hline \multirow[t]{3}{*}{5} & Overall & 23.52 & 74.50 & 21.56 & 90.19 \\
\hline & Boys & 23.52 & 74.50 & 21.56 & 90.19 \\
\hline & girls & - & - & - & - \\
\hline \multirow[t]{3}{*}{3} & Overall & 73.61 & 51.38 & 16.66 & 91.66 \\
\hline & Boys & 100.00 & 85.71 & 14.28 & 100 \\
\hline & girls & 70.76 & 47.69 & 16.92 & 90.76 \\
\hline \multirow[t]{3}{*}{7} & Overall & 69.87 & 65.06 & 21.68 & 97.59 \\
\hline & Boys & 68 & 92 & 16 & 96 \\
\hline & girls & 70.68 & 53.44 & 24.13 & 98.27 \\
\hline \multirow[t]{3}{*}{11} & Overall & 63.44 & 53.76 & 24.73 & 93.54 \\
\hline & Boys & 75 & 93.75 & 28.12 & 93.75 \\
\hline & Girls & 57.37 & 32.78 & 22.95 & 93.44 \\
\hline
\end{tabular}


Table 3. Descriptive statistics of achieving the Healthy Fitness Zone in percentages

\begin{tabular}{|c|c|c|c|c|}
\hline & Curl-Up & $\mathbf{9 0}^{\circ}$ Push Up & $\begin{array}{c}\text { Back-Saver } \\
\text { Sit \&Reach }\end{array}$ & $\begin{array}{c}\text { Shoulder } \\
\text { Stretch }\end{array}$ \\
\hline Overall & 67.55 & 70.00 & 21.95 & 92.1 \\
\hline Boys & 67.95 & 89.63 & 26.74 & 89.39 \\
\hline Girls & 67.16 & 50.37 & 17.17 & 94.81 \\
\hline
\end{tabular}

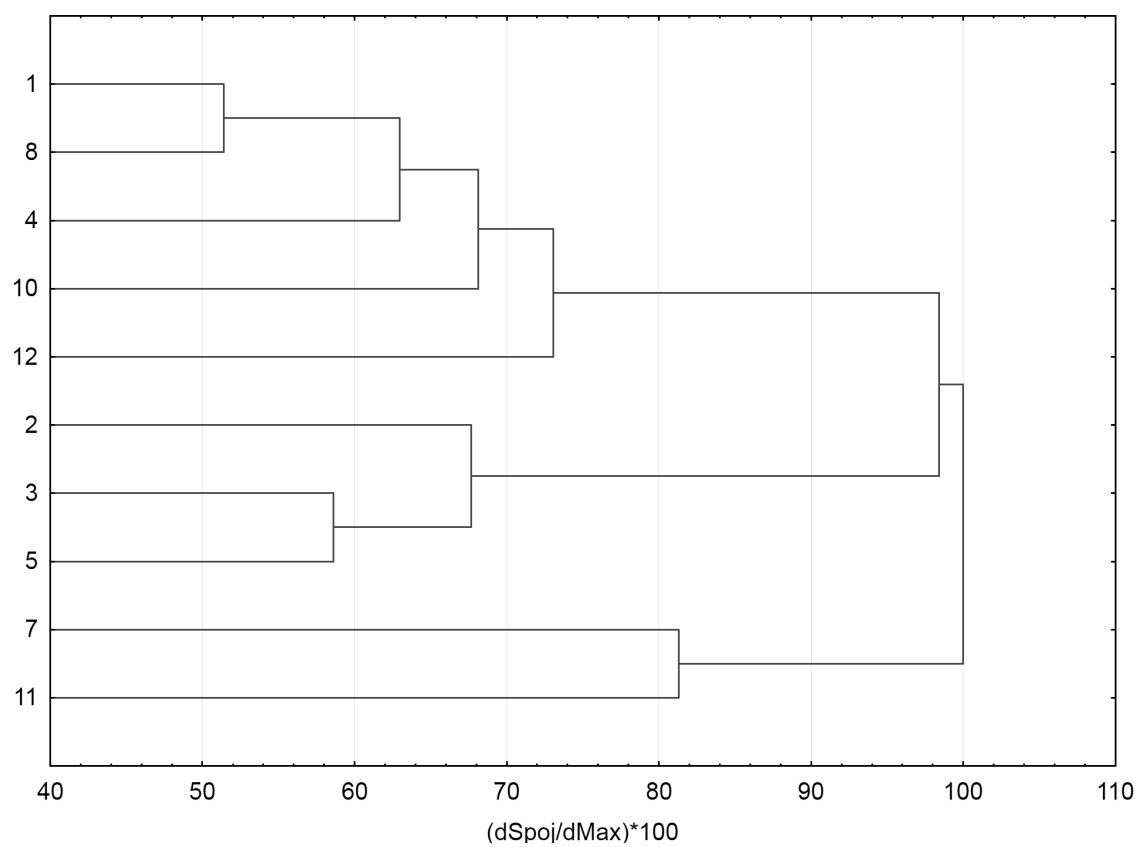

Figure 1. Cluster analysis of schools on the basis of the quality of environment

Note. 1 = High technical school in Stará L’ubovňa; $2=$ High school specializing in arts in Kežmarok; $3=$ High school specializing in health care in Prešov; $4=$ High school in Svit; $5=$ High school in Stropkov; $6=$ L. Stöckel's secondary grammar school in Bardejov; $7=$ Hotel Academy in Prešov; $8=$ High school academy of business in Vranov nad Topl'ou; $9=$ High school in Svidník; $10=$ Arm. gen. L. Svoboda's secondary grammar school in Humenné; $11=$ A. Prídavok's secondary grammar school in Sabinov; $12=$ Andy Warhol's high school in Medzilaborce. 
Table 4. Curl-Up

\begin{tabular}{|c|c|c|c|c|c|c|}
\hline & Parameter & Estimate & Lower Limit & Upper Limit & $\begin{array}{l}\text { Standard } \\
\text { Error }\end{array}$ & $p$-value \\
\hline \multirow{7}{*}{ 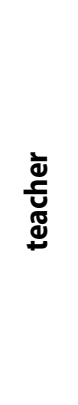 } & Intercept & -3.63 & -22.97 & 15.71 & 9.87 & 0.7128 \\
\hline & 2 & -1.02 & -5.43 & 3.38 & 2.25 & 0.6485 \\
\hline & 3 & 11.25 & 6.63 & 11.86 & 2.35 & 0.0000 \\
\hline & 5 & 6.62 & 0.56 & 12.69 & 3.09 & 0.0324 \\
\hline & 7 & -7.86 & -12.68 & -3.03 & 2.46 & 0.0014 \\
\hline & 8 & 10.17 & 1.73 & 18.62 & 4.31 & 0.0182 \\
\hline & 9 & -10.13 & -15.15 & -5.11 & 2.56 & 0.0001 \\
\hline \multirow{7}{*}{ 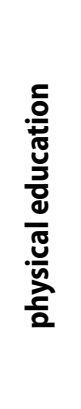 } & Intercept & 58.17 & 34.84 & 81.51 & 11.91 & 0.0000 \\
\hline & 10 & -2.29 & -4.89 & 0.32 & 1.33 & 0.0859 \\
\hline & 11 & -1.96 & -3.89 & -0.04 & 0.98 & 0.0456 \\
\hline & $12 a$ & 1.86 & -0.31 & 4.02 & 1.11 & 0.0927 \\
\hline & $12 b$ & -4.34 & -7.53 & -1.15 & 1.63 & 0.0076 \\
\hline & 14 & -1.26 & -2.60 & 0.08 & 0.68 & 0.0656 \\
\hline & 15 & 2.36 & -1.77 & 6.49 & 2.11 & 0.2632 \\
\hline \multirow{7}{*}{ 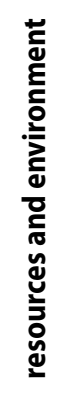 } & Intercept & 24.07 & 18.48 & 29.66 & 2.85 & 00000 \\
\hline & 17 & -7.79 & -13.71 & -1.89 & 3.02 & 0.0097 \\
\hline & 19 & -4.41 & -9.26 & 0.45 & 2.48 & 0.0752 \\
\hline & 20 & 4.43 & -0.81 & 9.68 & 2.68 & 0.0978 \\
\hline & 21 & 14.94 & 9.56 & 20.32 & 2.75 & 0.0000 \\
\hline & 23 & -0.90 & -5.76 & 3.95 & 2.48 & 0.7158 \\
\hline & 26 & -0.57 & -4.64 & 3.51 & 2.08 & 0.7850 \\
\hline \multirow{3}{*}{ 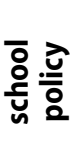 } & Intercept & 47.55 & 40.56 & 54.55 & 3.57 & 0.0000 \\
\hline & 28 & -0.66 & -2.21 & 0.88 & 0.79 & 0.4013 \\
\hline & 29 & -11.01 & -15.52 & -6.50 & 2.30 & 0.0000 \\
\hline
\end{tabular}

Note. $p<.05$ 
Table 5. $90^{\circ}$ Push-Up

\begin{tabular}{|c|c|c|c|c|c|c|}
\hline & Parameter & Estimate & Lower Limit & Upper Limit & $\begin{array}{c}\text { Standard } \\
\text { Error }\end{array}$ & p-value \\
\hline \multirow{7}{*}{ 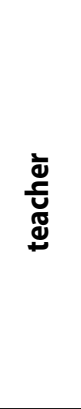 } & Intercept & -5.17 & -20.65 & 10.32 & 7.90 & 0.5131 \\
\hline & 2 & 8.84 & 5.32 & 12.36 & 1.79 & 0.0000 \\
\hline & 3 & -3.06 & -6.74 & 0.61 & 1.87 & 0.1020 \\
\hline & 5 & 3.92 & -0.95 & 8.78 & 2.48 & 0.1143 \\
\hline & 7 & 6.09 & 2.24 & 9.94 & 1.97 & 0.0019 \\
\hline & 8 & 1.85 & -4.83 & 8.54 & 3.41 & 0.5867 \\
\hline & 9 & -8.87 & -12.89 & -4.85 & 2.05 & 0.0000 \\
\hline \multirow{7}{*}{ 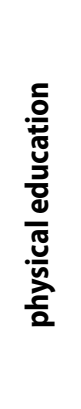 } & Intercept & 45.97 & 27.17 & 64.79 & 9.59 & 0.0000 \\
\hline & 10 & -4.31 & -6.42 & -2.19 & 1.08 & 0.0001 \\
\hline & 11 & -1.71 & -3.26 & -0.16 & 0.79 & 0.0308 \\
\hline & $12 a$ & 4.25 & 2.49 & 6.01 & 0.89 & 0.0000 \\
\hline & $12 b$ & -2.91 & -5.49 & -0.33 & 1.32 & 0.0270 \\
\hline & 14 & -0.11 & -1.19 & 0.97 & 0.55 & 0.8376 \\
\hline & 15 & -1.25 & -4.59 & 2.09 & 1.70 & 0.4637 \\
\hline \multirow{7}{*}{ 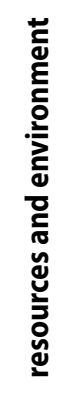 } & Intercept & 11.59 & 7.35 & 15.84 & 2.17 & 0.0000 \\
\hline & 17 & -13.18 & -17.73 & -8.63 & 2.32 & 0.0000 \\
\hline & 19 & 1.67 & -2.01 & 5.34 & 1.88 & 0.3741 \\
\hline & 20 & 2.77 & -1.22 & 6.77 & 2.04 & 0.1737 \\
\hline & 21 & 3.98 & -0.09 & 8.06 & 2.08 & 0.0553 \\
\hline & 23 & 14.40 & 10.71 & 18.09 & 1.88 & 0.0000 \\
\hline & 26 & 5.46 & 2.37 & 8.55 & 1.58 & 0.0005 \\
\hline \multirow{3}{*}{ 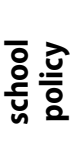 } & Intercept & 22.41 & 16.75 & 28.07 & 2.89 & 0.0000 \\
\hline & 28 & -0.99 & -2.25 & 0.25 & 0.64 & 0.1182 \\
\hline & 29 & 2.81 & -0.83 & 6.45 & 1.86 & 0.1303 \\
\hline
\end{tabular}

Note. $p<.05$ 
Table 6. Back-Saver Sit \& Reach

\begin{tabular}{|c|c|c|c|c|c|c|c|c|c|c|c|}
\hline & \multirow{2}{*}{ Parameter } & \multicolumn{2}{|c|}{ Estimate } & \multicolumn{2}{|c|}{ Lower Limit } & \multicolumn{2}{|c|}{ Upper Limit } & \multicolumn{2}{|c|}{ Standard Error } & \multicolumn{2}{|c|}{$p$-value } \\
\hline & & $\mathbf{R}$ & LL & $\mathbf{R}$ & L & $\mathbf{R}$ & L & $\mathbf{R}$ & $\mathbf{L}$ & $\mathbf{R}$ & $\mathbf{L}$ \\
\hline \multirow{7}{*}{ 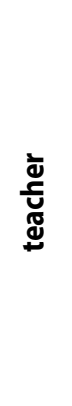 } & Intercept & 9.28 & 7.96 & 2.64 & 1.27 & 15.93 & 14.65 & 3.39 & 3.41 & 0.0062 & 0.0197 \\
\hline & 2 & -2.63 & -2.35 & -4.12 & -3.86 & -1.13 & -0.84 & 0.76 & 0.77 & 0.0006 & 0.0023 \\
\hline & 3 & 0.75 & 0.72 & -0.81 & -0.86 & 2.32 & 2.29 & 0.79 & 0.80 & 0.3454 & 0.3708 \\
\hline & 5 & -1.66 & -1.45 & -3.75 & -3.55 & 0.43 & 0.66 & 1.07 & 1.07 & 0.1195 & 0.1773 \\
\hline & 7 & 0.05 & 0.22 & -1.59 & -1.43 & 1.69 & 1.87 & 0.84 & 0.84 & 0.9503 & 0.7959 \\
\hline & 8 & -1.23 & -1.53 & -4.09 & -4.41 & 1.64 & 1.36 & 1.46 & 1.47 & 0.4017 & 0.2993 \\
\hline & 9 & 2.28 & 2.13 & 0.56 & 0.40 & 3.99 & 3.86 & 0.88 & 0.88 & 0.0092 & 0.0156 \\
\hline \multirow{7}{*}{ 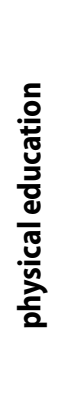 } & Intercept & -8.12 & -9.97 & -15.87 & -17.78 & -0.37 & -2.16 & 3.95 & 3.99 & 0.0401 & 0.0124 \\
\hline & 10 & 2.21 & 2.34 & 1.34 & 1.46 & 3.08 & 3.22 & 0.44 & 0.45 & 0.0000 & 0.0000 \\
\hline & 11 & -0.31 & -0.19 & -0.95 & -0.84 & 0.33 & 0.45 & 0.33 & 0.33 & 0.3395 & 0.5567 \\
\hline & $12 a$ & -1.76 & -1.79 & -2.49 & -2.53 & -1.04 & -1.07 & 0.37 & 0.37 & 0.0000 & 0.0000 \\
\hline & $12 b$ & 3.19 & 3.22 & 2.13 & 2.15 & 4.26 & 4.29 & 0.54 & 0.55 & 0.0000 & 0.0000 \\
\hline & 14 & 0.39 & 0.33 & -0.05 & -0.12 & 0.85 & 0.78 & 0.23 & 0.23 & 0.0806 & 0.1551 \\
\hline & 15 & 0.58 & 0.85 & -0.79 & -0.53 & 1.95 & 2.24 & 0.70 & 0.71 & 0.4100 & 0.2274 \\
\hline \multirow{7}{*}{ 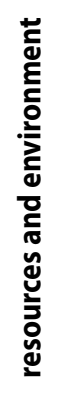 } & Intercept & 5.49 & 4.81 & 3.66 & 2.96 & 7.32 & 6.65 & 0.93 & 0.94 & 0.0000 & 0.0000 \\
\hline & 17 & 3.84 & 3.34 & 1.89 & 1.38 & 5.79 & 5.30 & 0.99 & 0.99 & 0.0001 & 0.0008 \\
\hline & 19 & -0.87 & -0.62 & -2.47 & -2.23 & 0.72 & 0.99 & 0.82 & 0.82 & 0.2841 & 0.4485 \\
\hline & 20 & 0.54 & 1.20 & -1.18 & -0.53 & 2.26 & 2.94 & 0.88 & 0.88 & 0.5375 & 0.1726 \\
\hline & 21 & -1.13 & -1.19 & -2.89 & -2.96 & 0.63 & 0.58 & 0.89 & 0.90 & 0.2065 & 0.1885 \\
\hline & 23 & -3.77 & -3.68 & -5.37 & -5.29 & -2.18 & -2.07 & 0.81 & 0.82 & 0.0000 & 0.0000 \\
\hline & 26 & -0.79 & -0.86 & -2.13 & -2.22 & 0.55 & 0.49 & 0.69 & 0.69 & 0.2491 & 0.2115 \\
\hline \multirow{3}{*}{ 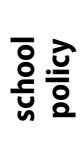 } & Intercept & 5.13 & 5.16 & 2.76 & 2.78 & 7.50 & 7.54 & 1.21 & 1.22 & 0.0000 & 0.0000 \\
\hline & 28 & 0.63 & 0.59 & 0.11 & 0.06 & 1.15 & 1.12 & 0.27 & 0.27 & 0.0185 & 0.0279 \\
\hline & 29 & -2.63 & -2.83 & -4.15 & -4.36 & -1.11 & -1.29 & 0.78 & 0.78 & 0.0007 & 0.0003 \\
\hline
\end{tabular}

Note. $R=$ right; $L=$ left $; p<.05$ 
Table 7. Shoulder Stretch

\begin{tabular}{|c|c|c|c|c|c|c|}
\hline & Parameter & Estimate & Lower Limit & Upper Limit & $\begin{array}{l}\text { Standard } \\
\text { Error }\end{array}$ & $p$-value \\
\hline \multirow{7}{*}{ 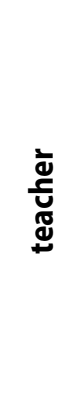 } & Intercept & 0.99 & 0.75 & 1.24 & 0.12 & 0.0000 \\
\hline & 2 & -0.03 & -0.08 & 0.03 & 0.03 & 0.3374 \\
\hline & 3 & -0.01 & -0.07 & 0.05 & 0.03 & 0.7094 \\
\hline & 5 & -0.02 & -0.09 & 0.06 & 0.04 & 0.6591 \\
\hline & 7 & 0.01 & -0.05 & 0.07 & 0.03 & 0.7034 \\
\hline & 8 & -0.03 & -0.13 & 0.078 & 0.05 & 0.6085 \\
\hline & 9 & 0.08 & 0.01 & 0.14 & 0.03 & 0.0171 \\
\hline \multirow{7}{*}{ 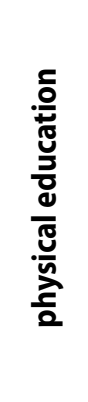 } & Intercept & 0.75 & 0.47 & 1.03 & 0.14 & 0.0000 \\
\hline & 10 & 0.04 & 0.004 & 0.07 & 0.02 & 0.0273 \\
\hline & 11 & -0.004 & -0.03 & 0.02 & 0.01 & 0.6748 \\
\hline & $12 a$ & -0.03 & -0.06 & -0.008 & 0.01 & 0.0102 \\
\hline & $12 \mathrm{~b}$ & 0.07 & 0.03 & 0.11 & 0.02 & 0.0004 \\
\hline & 14 & 0.005 & -0.01 & 0.02 & 0.008 & 0.5706 \\
\hline & 15 & -0.008 & -0.06 & 0.04 & 0.03 & 0.7569 \\
\hline \multirow{7}{*}{ 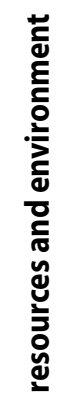 } & Intercept & 0.92 & 0.85 & 0.99 & 0.04 & 0.0000 \\
\hline & 17 & 0.06 & -0.02 & 0.13 & 0.04 & 0.1432 \\
\hline & 19 & 0.02 & -0.04 & 0.09 & 0.03 & 0.4269 \\
\hline & 20 & 0.05 & -0.02 & 0.12 & 0.03 & 0.1448 \\
\hline & 21 & -0.08 & -0.15 & -0.01 & 0.03 & 0.0206 \\
\hline & 23 & -0.02 & -0.08 & 0.04 & 0.03 & 0.5632 \\
\hline & 26 & -0.03 & -0.08 & 0.02 & 0.03 & 0.2789 \\
\hline \multirow{3}{*}{ 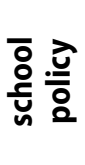 } & Intercept & 0.92 & 0.83 & 1.00 & 0.04 & 0.0000 \\
\hline & 28 & 0.002 & -0.02 & 0.02 & 0.009 & 0.8279 \\
\hline & 29 & -0.004 & -0.06 & 0.05 & 0.03 & 0.8884 \\
\hline
\end{tabular}

Note. $p<.05$ 
Table 8. Final table of effects of school variables on achieving the HFZ

\begin{tabular}{|c|c|c|c|c|c|c|}
\hline & \multirow{2}{*}{ Parameter } & \multirow{2}{*}{ Curl Up } & \multirow{2}{*}{$90^{\circ}$ Push-Up } & \multicolumn{2}{|c|}{ Back-Saver Sit\&Reach } & \multirow{2}{*}{$\begin{array}{l}\text { Shoulder } \\
\text { Stretch }\end{array}$} \\
\hline & & & & $\mathbf{L}$ & $\mathbf{R}$ & \\
\hline \multirow{7}{*}{ 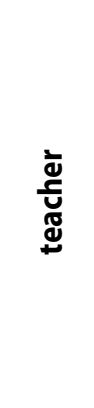 } & Intercept & & & + & + & + \\
\hline & 2 & & + & - & - & \\
\hline & 3 & + & & & & \\
\hline & 5 & + & & & & \\
\hline & 7 & - & + & & & \\
\hline & 8 & + & & & & \\
\hline & 9 & - & - & + & + & - \\
\hline \multirow{7}{*}{ 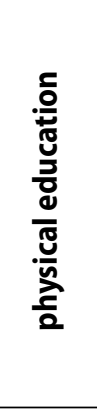 } & Intercept & + & + & - & - & + \\
\hline & 10 & & - & + & + & + \\
\hline & 11 & - & - & & & \\
\hline & $12 \mathrm{a}$ & & + & - & - & - \\
\hline & $12 b$ & - & - & + & + & + \\
\hline & 14 & & & & & \\
\hline & 15 & & & & & \\
\hline \multirow{7}{*}{ 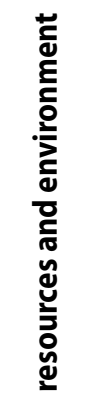 } & Intercept & + & + & + & + & + \\
\hline & 17 & - & + & + & + & \\
\hline & 19 & & & & & \\
\hline & 20 & & & & & \\
\hline & 21 & + & + & & & - \\
\hline & 23 & & + & - & - & \\
\hline & 26 & & + & & & \\
\hline \multirow{3}{*}{ 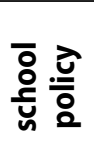 } & Intercept & + & + & + & + & + \\
\hline & 28 & & & + & + & \\
\hline & 29 & - & & - & - & \\
\hline
\end{tabular}

Note. $\mathrm{R}=$ right; $\mathrm{L}=$ left; plus (+) and minus (-) sings indicate the variable was positively or negatively associated with achieving the HFZ; blank areas denote no association; $p<.05$

\section{Corresponding author}

Mgr. Lenka Tlučáková, PhD.

Fakulta športu, Prešovská univerzita v Prešove, Prešov, Slovakia lenka.tlucakova@unipo.sk 